\title{
Oil pollution in the North Sea: the impact of governance measures on oil pollution over several decades
}

\author{
Angela Carpenter $(\mathbb{D}$
}

Received: 4 April 2017/Revised: 22 February 2018/Accepted: 24 February 2018/Published online: 12 March 2018

(C) The Author(s) 2018. This article is an open access publication

\begin{abstract}
Oil pollution entering the marine environment has been an issue of concern for many decades. It can come from riverine or land-based sources, accidental and intentional discharges from ships, or as a by-product of offshore oil extraction. Growing awareness of the impact of oil pollution on the marine environment has led, since the late 1960s, to the introduction of measures to reduce or eliminate pollution from shipping and the offshore oil industry. A framework for environmental protection of the North Sea has developed over many decades through international agreements, regional cooperation, and national measures, while education has also played an important role with modern-day sailors being given due training to understand that dumping waste at sea is illegal in many areas, and is harmful to the marine environment. This paper presents data on trends in pollution from ships and oil installations. While significant reductions in oil pollution have been identified over more than two decades, there remain some areas where action is needed to reduce inputs still further, especially from oil and gas platforms.
\end{abstract}

Guest editors: Steven J. Degraer, Vera Van Lancker, Silvana N.R. Birchenough, Henning Reiss \& Vanessa Stelzenmüller / Interdisciplinary research in support of marine management

A. Carpenter $(\square)$

School of Earth and Environment, University of Leeds, Leeds LS2 9JT, UK

e-mail: a.carpenter@leeds.ac.uk
This paper illustrates that international cooperation can result in a reduction in marine pollution leading to a cleaner environment.

Keywords Oil pollution · North Sea .

Environmental monitoring · Environmental policy ·

Regional cooperation $\cdot$ Monitoring and surveillance

\section{Introduction}

Oil pollution-petroleum hydrocarbons-can enter the marine environment from a wide range of sources including transport (e.g. tanker operations or accidents, bilge and fuel oil, non-tanker accidents and atmospheric emissions), from fixed installations (coastal refineries, offshore production, marine terminals) and from other sources (e.g. municipal or industrial waste, urban or river run-off), together with natural inputs (Clark, 2001). Contamination by oil fractions may persist in the marine environment for many years after an oil spill, depending on characteristics of oil such as type, spill size and location (Tansel, 2014). In areas such as salt marshes and mangrove swamps, the environment may recover fairly quickly (within 2-10 years) (Kingston, 2002). However, where a spill is not dealt with through the physical removal of oil, it can persist for more than 25 years (Kingston, 2002). 
A range of biological effects can result from chronic oil inputs such as repeated small spillages in coastal waters, with those effects ranging from localised and subtle to severe and long lasting (Dicks \& Hartley, 1982). For example, in the UK sector of the North Sea there is evidence to show that the impacts of drilled cuttings (solid material removed from drilled rock, together with muds and chemicals) containing oil-based muds can persist for at least 6-8 years where cutting piles accumulate at the base of a drilling platform (Henry et al., 2017). Experiments into the impacts of sediments from offshore drilling activities, including large amounts of drilling cuttings have shown a significant reduction in number of taxa, abundance, biomass and diversity when cuttings were added to natural sedimentation thresholds (Schaanning et al., 2008; Trannum et al., 2010). The disturbance caused by drilling has been shown to have an impact on deep-water megafaunal density and diversity, for example, with recovery and recolonisation being only partial after 3 years, and the effects of such activities being still visible after a decade (Jones et al., 2012). Colonies of the cold-water corals, Lophelia pertusa, have been identified around many oil and gas platforms in the northern North Sea (Gass \& Roberts, 2006; Purser \& Thomsen, 2012), and there is evidence to suggest that coverage of coral colonies by sediments, including cuttings from oil platforms, is sufficient to damage or even kill such colonies, despite their resilience to short-term sedimentation events (e.g. Allers et al., 2013; Larsson et al., 2013).

Oil spills have also been shown to have a detrimental impact on deep-water coral communities in warmer waters, as in the case of the Deepwater Horizon (Macondo well) oil spill in 2010 in the Gulf of Mexico. In this example there was evidence of damaged and deceased coral colonies at around $11 \mathrm{~km}$ from the spill site, approximately 3 months after the well was capped (White et al., 2012). The Deepwater Horizon oil spill also had an acute impact the abundance and composition of bacterial communities in beach sands in the Gulf of Mexico (Kostka et al., 2011), on marsh vegetation in coastal saltmarshes in the Barataria Bay of Louisiana in the northern Gulf of Mexico (Lin \& Mendelssohn, 2012), and on the wetlands of the Mississippi River Delta system in Louisiana, an area responsible for approximately one-third of US commercial fish production (Mendelssohn et al., 2012). Commercial fisheries are at particular risk of harm from oil pollution, particularly where a slick occurs near to farmed fish or shellfish operations, or close to breeding grounds where fish eggs and larvae are vulnerable to oil pollution, (e.g. Clark, 2001). In addition to the direct impacts of the Deepwater Horizon oil spill was an associated impact from the use of dispersants on marine copepods. Cohen et al. (2014) demonstrated an acute effect of a dispersant (Corexit EC9500A) with increased mortality rates of the common coastal copepod Labidocera aestiva exposed to that dispersant alone; exposure to crude oil alone or in combination with that dispersant impacted on the swimming behaviour of Labidocera aestiva. This illustrates a need to understand not only the direct impacts of oil on marine taxa, but also, for example, the additional impacts of dispersants as a method of cleaning up oil spills.

The volumes of oil entering the marine environment each year are unclear. Clark (2001), for example, suggests that globally around 4.63 million tonnes per year entered the marine environment from transportation (including 0.163 million tonnes from tanker operations and 0.162 million tonnes from tanker accidents) and 0.18 million tonnes from fixed installations including offshore oil production, the main sources discussed in this paper. A 2007 estimate by the European Environment Agency (EEA, 2007, p. 232) indicates that between 1 and 3 million tonnes per year of oil enters the global marine environment, of which $24 \%$ is from marine transport (18\% from operational ship discharges and $6 \%$ from accidental spills) and $3 \%$ from offshore extraction.

In terms of oil inputs to the marine environment of the North Sea, estimated volumes of oil also vary widely. Bedborough et al. (1987) provide a range of estimates for petroleum hydrocarbon inputs from all sources to the North Sea as a whole ranging from 107,000 to 165,000 tonnes, of which between 23,700 and 26,100 tonnes came from offshore operations in the region during the period 1982-1983. More recent figures for oil discharges from offshore oil and gas installations indicate that 4231 tonnes of oil (discharges and spills) entered the North Sea in 2014, down from 8756 tonnes in 2005 (OSPAR Commission, 2016, p. 42). These figures illustrate a significant decline in pollution from oil and gas production activities over several decades, and a number of measures have been put in place in the region to reduce 
such pollution. Measures are also in place to reduce or prevent oil pollution from shipping (accidental and intentional discharges) in the region. This paper presents a discussion on measures in place to reduce oil pollution in the North Sea, and on the effectiveness of those measures. The paper is structured in the following way: it examines the various measures developed internationally since the mid-1950s; it then identifies trends in oil pollution from shipping, and from oil and gas installations; it identifies some areas for potential future research; and finally it draws conclusions about the effectiveness of policy measures, aided by monitoring and surveillance activities, in reducing marine pollution in the North Sea region over many decades.

\section{Measures to protect the North Sea from oil pollution}

The North Sea has seen high levels of oil pollution for the past many decades with Dunnet et al. (1987) indicating that, since the early years of the twentieth century, oil pollution at sea continuously caused the contamination and deaths of seabirds. Potential sources of oiling of seabirds included tanker accidents, spills at terminals and offshore loading facilities, and blowouts at wells and production installations (e.g. Dunnet et al., 1987). In the case of the Netherlands, ${ }^{1}$ evidence of pollution in its waters dates back to 1915 . Camphuysen \& Vollaard (2015) note that the first accounts of oil pollution in Netherlands waters were published early in 1915 when oiled birds were washed ashore along the Netherlands mainland coast, and that there had been similar reports prior to the First World War of birds washing ashore on the coast of the UK. Large numbers of oiled seabirds continued to be washed ashore on the Netherlands coast at various times in the 1920s, 1930s and 1940s which were indicative of offshore oil spills or leaks (Camphuysen \& Vollaard, 2015). This trend continued during the twentieth century, with evidence of chronic oil pollution becoming apparent through the high rate of oiled seabirds being washed ashore on the Netherlands

\footnotetext{
1 "Netherlands waters" and "Dutch waters" are both used to cover the waters of the Netherlands. While the paper referred to uses "Dutch waters", for consistency in this paper "Netherlands" has been used throughout
}

coastline every winter during the 1950 s to 1970 s, before a gradual decline in numbers during the 1980s and 1990s (see also Camphuysen \& Heubeck, 2015).

The International Convention for the Pollution of the Sea by Oil (OILPOL) of 1954 was the first measure to set operational discharge standards for oil from ships, with amendments in 1962 and 1969 subsequently imposing more stringent limits within specific zones (Molenaar, 1998). Growing awareness of the impact of oil pollution on the marine environment led, in the late $1960 \mathrm{~s}$, to the introduction of stricter measures to reduce or eliminate pollution from shipping and the offshore oil industry in the region. In particular, the grounding of the oil tanker Torrey Canyon on the Seven Sisters Reef between the Scilly Isles and Lands' End (UK) in February 1967, and the subsequent spill of 119,000 tonnes of crude oil, resulted in questions being raised about how to prevent such accidents from happening again or, if they did, how to minimise their impacts and how to provide compensation in the event of another spill. The Torrey Canyon event also led to the introduction of two international measures: the International Convention on Civil Liability for Oil Pollution Damage in 1969 (see IMO, 2015a) and the International Convention for the Prevention of Pollution from Ships (MARPOL Convention) in 1973, which was subsequently modified by the Protocol of 1978 relating thereto (see IMO, 2015b).

At an international level, the International Maritime Organization (IMO), ${ }^{2}$ a specialised agency of the United Nations, is tasked with global standard setting for safety, security and environmental performance of international shipping. The IMO has adopted over 25 Conventions in the field of marine pollution alone including the MARPOL Convention, mentioned above, and a number of other conventions included in Table 1. That table sets out a range of measures that provide a framework for environmental protection of the North Sea, developed over many decades, and includes international, regional and EU governance measures.

The two main regional agreements relating to oil are the Bonn Agreement and the OSPAR Convention (see Table 1). This paper considers, in particular, the

\footnotetext{
${ }^{2}$ For further information on the role of the International Maritime Organization, see: http://www.imo.org/en/About/ Pages/Default.aspx.
} 
Table 1 Legislation relating to marine pollution by oil in the North Sea

Year Legislative measure

1954 International convention for the pollution of the sea by oil (OILPOL)

1969 Agreement for cooperation in dealing with pollution of the North Sea by Oil (Bonn Agreement)

1969 International convention relating to intervention on the high seas in cases of oil pollution casualties (INTERVENTION)

1972 Convention for the prevention of marine pollution by dumping from ships and aircraft (Oslo convention)

1972 International convention on the prevention of marine pollution by dumping of wastes and other matter (London dumping convention)

1973 International convention for the prevention of pollution from ships (MARPOL)—Annex I of this Convention specifically deals with Regulations for the Prevention of Pollution by Oil

1974 Convention for the prevention of marine pollution from land-based sources (Paris Convention)

1978 Protocol to the international convention for the prevention of pollution from ships (MARPOL 73/78)

1982 Memorandum of understanding on port state control in implementing agreements on maritime safety and protection of the marine environment (Paris MOU

1983 Agreement for cooperation in dealing with pollution of the North Sea by Oil and other harmful substances (Bonn Agreement)—superseding 1969 Agreement

1990 International convention on oil pollution preparedness, response and cooperation (OPRC)

1992 Convention for the protection of the marine environment of the north-east atlantic (OSPAR Convention; superseding Oslo and Paris Conventions)—ratified 1998

2000 EU Directive 2000/59/EC on provision of Port Reception Facilities for ship-generated waste and cargo residues (entered into force 2002) (with the obligation for ports in EU MSs to provide adequate reception facilities, including oily waste facilities, for ships normally calling into them)

2005 EU Directive 2005/35/EC on ship-source pollution and the introduction of penalties for infringements (with the obligation for EU MSs to prosecute)

2008 EU Directive 2008/56/EC establishing a framework for community action in the field of marine environmental policy (Marine Strategy Framework Directive, MSFD) (with the obligation for EU MSs to monitor in the field)

2009 EU Directive 2009/16/EC on Port State Control (with the binding obligation for EU MSs to perform a certain level of port inspections of ships against a range of standards/relevant instruments).

roles played by the Bonn Agreement (http://www. bonnagreement.org/) in monitoring oil pollution from ships and from oil and gas installations, as illustrated in Fig. 1, and of the OSPAR Commission (http:// www.ospar.org/) in setting standards to protect the marine environment from the adverse effects of offshore activities. These organisations work closely together to detect and combat pollution both from maritime disasters and from chronic pollution from ships and offshore installations (OSPAR Commission, 2010, p. 93).

While data provided by the Bonn Agreement Aerial Surveillance Reports can identify whether some oil spills are associated with either shipping activities or oil installations, for around $80 \%$ of slicks detected by aerial surveillance, it was not possible to identify the source, as highlighted in Fig. 1. It is important to note that spills from ships carrying oil and other hazardous or toxic substances may have severe short or long-term impacts on marine ecosystems, depending on weather conditions, location, and the ecological sensitivity of the area around a spill (OSPAR Commission, 2010, p. 95). As Tansel (2014) notes, the BP Gulf Oil Spill (Deepwater Horizon spill) was the worst oil spill ever in terms of impact, economic cost, and vulnerability of the geographical location, even though it was not the largest ever spill in terms of volume.

\section{Trends in oil pollution from shipping activities in the North Sea}

A wide range of human activities occur in the North Sea region, ranging from shipping, energy production, waste disposal, and dredging/aggregate extraction. The North Sea region has some of the world's busiest shipping routes, serving the largest commercial ports in Europe (Rotterdam, Antwerp and Hamburg). For 
Fig. 1 Confirmed Oil Slicks from all sources, 1997-2013. Figures 1 and 2, together with Tables 3, 4 and 5, have been compiled using data from Bonn Agreement Annual Aerial Surveillance Reports available for the years 1986-2014. Early reports were in paper format only. The 2008 and subsequent annual reports are available online at: http://www. bonnagreement.org/ activities/aerialsurveillance. Source Bonn Agreement Annual Aerial Surveillance Reports 1998-2014

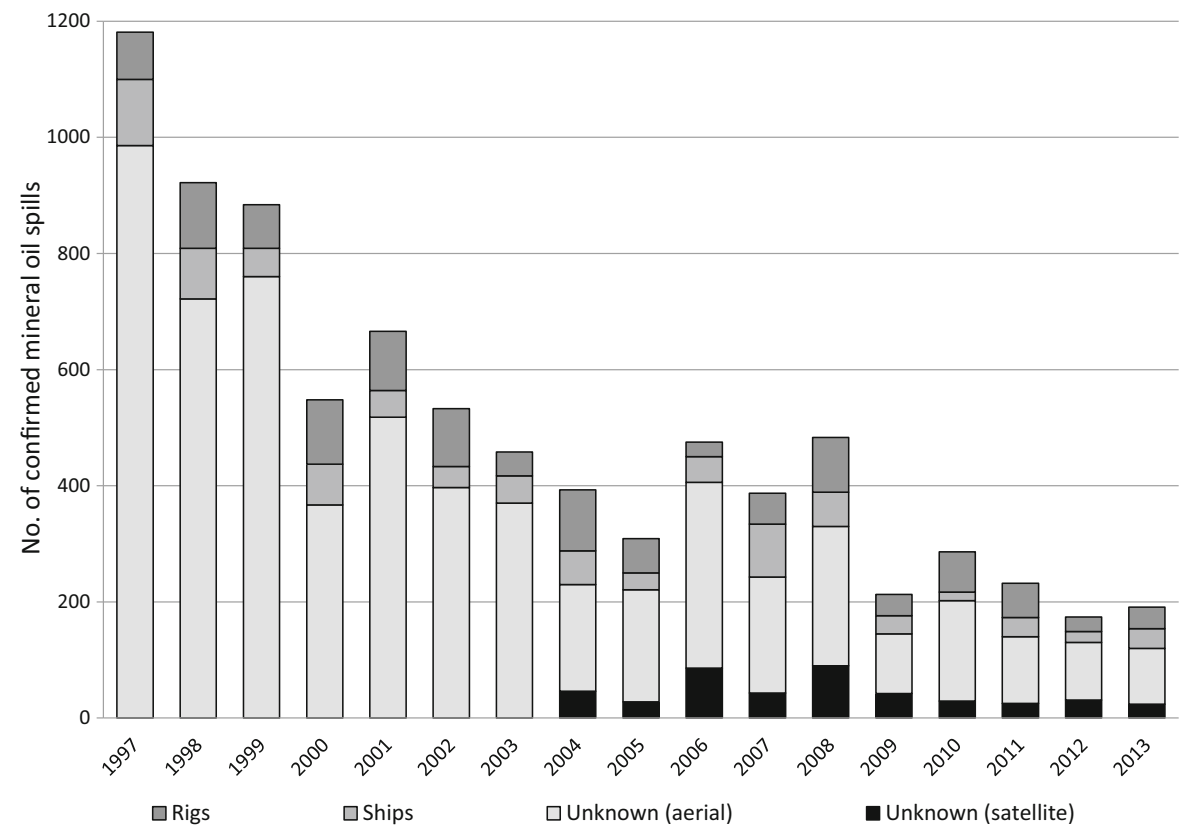

example, in the English Channel, Porathe \& Ottmann (2015) identified that there were 131,444 ship movements of all vessel types recorded as passing through the Dover Strait in 2012 (approximately one every $4 \mathrm{~min}$ ), together with multiple short-sea shipping movements by cross-Channel ferries. Other high traffic areas in the region include the route through the waters of Belgium, Netherlands and Germany entering the ports of Rotterdam, Antwerp, Ijmuiden/ Amsterdam, Hamburg and Bremerhaven (with 58,412 vessels crossing through that area), while high numbers of vessels $(54,448)$ pass between the Baltic and the North Seas via the Skagerrak between Denmark and Norway each year. Porathe \& Ottmann (2015) forecast that those figures will have increased to $200,000,90,000$ and 80,000, respectively, by 2020 , based on a predicted $50 \%$ increase in the number of shipping movements in the North Sea, while the Bonn Agreement (2014a, p. 18) indicates that there will be ongoing annual growth in the number of oil tankers and LNG/LPG/Gas tankers in the region through to 2020 , the types of vessels that pose the highest risk of a major oil spill in the event of an accident. Increased shipping numbers also increase the potential for smaller oil spills that could wash ashore and damage coastal wetlands and marshes, or damage commercial fishing activities, for example.
The continued increase in the numbers of vessels travelling through the North Sea region will result in ever more crowded shipping lanes, ships competing for space with, for example, the many planned and proposed offshore windfarm sites located in the navigable space of the North Sea; predicted to increase from around $400 \mathrm{~km}^{2}$ to around $23,500 \mathrm{~km}^{2}$ over the next few years (Porathe \& Ottmann, 2015). This highlights the importance of having in place measures and activities to ensure that vessel movements are monitored to ensure their safety, and the safety of other activities, within the region.

The role of the Bonn Agreement in oil pollution monitoring

In 1969, the Agreement for Cooperation in Dealing with Pollution of the North Sea by Oil (Bonn Agreement) was established in order to aid in the protection of the marine environment of the North Sea region, in the event of oil pollution incidents (see Bonn Agreement, 2001). The Bonn Agreement has, for several decades, played a significant role in pollution monitoring in the region. Contracting Parties (CPs) to the Agreement conduct a range of aerial surveillance flights, both at national level and regionally, through coordinated operations conducted by neighbouring (not necessarily Bonn Agreement) countries, 
Fig. 2 Bonn Agreement aerial surveillance data for all the North Sea Countries, 1986-2013. Source Bonn Agreement Annual Aerial Surveillance Reports 1998-2014

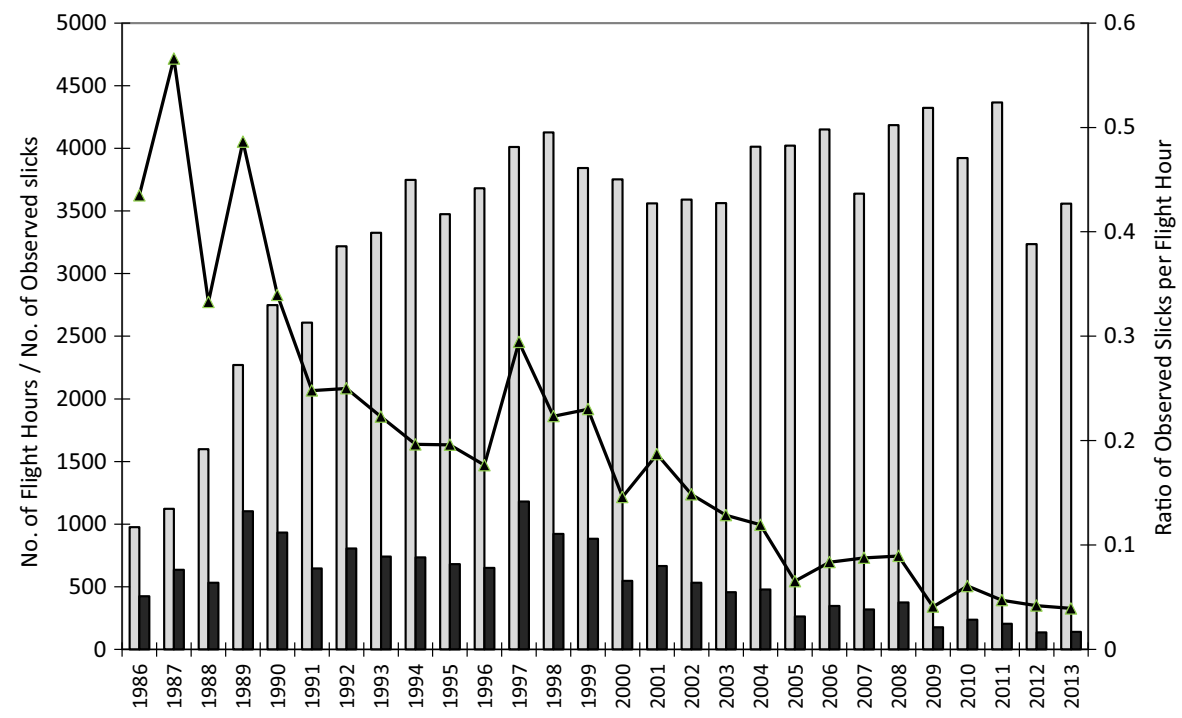

$\square$ flight hours $\square$ observed slicks -4-ratios including flights to monitor oil and gas installations (Bonn Agreement, 2012a, pp. 7-8). Flights take place during both daylight hours and the hours of darkness, using a range of different sensors (Bonn Agreement, 2012a, pp. 4-6). In addition, satellite surveillance, conducted through the European Maritime Safety Agency (EMSA) CleanSeaNet Programme has, for more than 10 years, supplemented national aerial surveillance activities by providing near real-time radar images of potential spills using synthetic aperture radar (SAR) satellites, and with potential spills being reported to coastal states within approximately $30 \mathrm{~min}$ of being detected (EMSA, 2015).

Figure 2 presents the level of aerial surveillance activity which took place across the North Sea between 1986 and 2013, and the number of observed spills identified during that surveillance activity. From 1992 onwards, the data include surveillance activities both in daylight and during the hours of darkness, while from 2003 onwards, the numbers of observed spills make a distinction between detections and confirmed mineral oil spills, the latter being spills where visual verification from an aircraft has taken place. ${ }^{3}$ Some caveats need to be considered with this data, however. Prior to 2003 only the annual number of reported spills was reported by CPs to the Bonn

\footnotetext{
${ }^{3}$ For more information on the identification of oil spills on the sea surface, see the Bonn Agreement Oil Appearance CodePhoto Atlas (Bonn Agreement, 2011).
}

Agreement Secretariat which compiles the data for the annual surveillance reports. CPs generally fly only in daylight conditions, although the Netherlands, in particular, undertakes a large number of flights during the hours of darkness. As a result, spills detected using Side-Looking Airborne Radar (SLAR; imaging radar pointing perpendicular to the direction of flight, mounted on an aircraft or satellite) can be immediately verified visually by the aircrew. In the case of night detections, these cannot be immediately verified without additional observations and so were not generally reported to the Bonn Agreement. While some CPs did report such unconfirmed night observations, and also some observed spills that were other harmful substances, BA experts consider that the uncertainty range of the data to 2003 is low, since the majority of flights took place in daylight conditions and most spills at sea were verified as being mineral oil.

Further areas where there is uncertainty in the surveillance data relate to the various types of aircraft used to undertake aerial surveillance flights, the types of sensors on board, and the speed of the aircraft. The Bonn Agreement (2004) identified a wide range of different aircrafts operated by CPs, each with different sensors on board. Sensors need to be compatible with the specific aircraft's power supply (Bonn Agreement, 2004, p. 4), and a wide range of sensors are available, including SLAR, SAR, Ultra Violet or Infrared Line 
Scanners or Cameras, and Night Identification Systems, for example (Bonn Agreement, 2012a, pp. 4-7). The speed of the aircraft can significantly influence the number of observed spills per flight hour, since the faster the plane the greater the area that can be covered in one hour. An attempt to standardise aircraft speeds took place between 2000 and 2002, when a 'BA flight hour' was introduced, i.e. one hour of airborne remote sensing over the sea at a standardised speed of $335 \mathrm{~km}$ per hour (Bonn Agreement, 2014b, pp. 5-6). Prior to 2000 , flight hour data were based in absolute figures, while between 2000 and 2002, they were standardised on SLAR coverage and were corrected for the relative speed of aircraft. However, average aircraft speeds were significantly different for some CPs, for example, Belgium and the UK, and so data for periods up to 1999, and for those from 2000 to 2002 were not comparable. From 2003 onwards, absolute numbers were reintroduced (Bonn Agreement, 2014b, p. 7).

Since 2004, the percentage of spills confirmed as mineral oil has varied greatly between those detected initially by satellite imagery and those detected by aerial surveillance. Table 2 sets out the percentage of confirmed mineral oil spills from those originally detected by satellite or aerial detection activities for the years 2004-2013 in the North Sea region.

Table 2 illustrates that a far higher proportion of slicks originally identified using aerial surveillance are confirmed as being mineral oil (more than $50 \%$ in most years and as high as $80 \%$ in 2004) compared to those identified by satellite imagery techniques (just over $21 \%$ in 2006 and as low as $3.8 \%$ in 2013). However, in all cases, visual observation and verification by welltrained air crew is necessary to unambiguously confirm that an observed slick is composed of mineral oil (Bonn Agreement, 2016, p. 5). There is some inflexibility in the system for obtaining satellite SAR images due to the fixed orbit of satellites, for example, although satellite recordings may have some advantages as they are independent of weather conditions that might prevent an aircraft from flying, and the width of the radar coverage path increases the area that can be covered by each satellite pass (Bonn Agreement, 2012, p. 108). The use of satellites can be considered to have increased the likelihood of potential oil spills being detected on the sea surface due to their greater area coverage. In addition, the use of satellites to track vessels using AIS data (automatic information system data, based on the transmission of very high frequency radio signals to track ship movements), means that it may be possible to attribute an oil spill to a specific ship by identifying which ships were in the location where a spill occurred (EMSA, 2011).

Types of oil pollution from shipping activities

Oil pollution from ships can come from a range of different activities, including legal discharges, intentional or illegal discharges, and accidental spills. Illegal discharges occur when a ship fails to adhere to the relevant discharge standards for operational activities, or choose to intentionally discharge oil out of sight of land and during the hours of darkness, for example. Major accidental spills in the region are very rare, although two such spills in the North East Atlantic and the North Sea were 7th and 14th, respectively, in the top 20 major spills between 1967 and 2002. These were the Torrey Canyon in 1967, and the grounding of the MV Braer on the rocks of Garths Ness on Shetland in 1993, the latter resulting in a spill of around 85,000 tonnes of oil.

While accidents are generally unpredictable or unavoidable, it is possible to restrict legal discharges. These occur where a ship is allowed to discharge a certain level of oil in water (15 parts per million; ppm) during normal operational activities such as discharging bilge water or cleaning out oily waters from its cargo tanks. However, the North Sea, as part of the North West European Waters, was granted Special Area (SA) Status under MARPOL 73/78 Annex I: Oil in September 1997 (entry into force February 1999). As a result, the region benefits from a higher level of protection than other areas of the sea (IMO, 2017a). Lying between Denmark, Germany and the Netherlands, the Wadden Sea, which contains the world's largest tidal flats system, large areas of coastal salt marshes, accommodates over 5,000 species of flora and fauna, and attracts over 10 million migratory seabirds annually (UNESCO, 2017). The Wadden Sea area was granted Particularly Sensitive Sea Area (PSSA) status in 2002, with oil discharges in that area being even more tightly restricted than for the rest of the North Sea SA (IMO, 2017b). This is significant since, should a major oil spill occur in the Wadden Sea, the impacts of oil are likely to be highly damaging and long lasting. For example, heavy oiling resulting from the Deepwater Horizon oil spill has been shown 
Table 2 Percentage of spills confirmed as mineral oil from detections using satellite imagery and aerial surveillance, $2003-2013$. Source Bonn Agreement Annual Aerial Surveillance Reports 2004 to 2014

\begin{tabular}{|c|c|c|c|c|c|c|}
\hline \multirow[t]{2}{*}{ Year } & \multicolumn{3}{|c|}{ Satellite imagery data } & \multicolumn{3}{|c|}{ Aerial surveillance data } \\
\hline & Spills detected & Confirmed as mineral oil & $\%$ confirmed & Spills detected & Confirmed as mineral oil & $\%$ confirmed \\
\hline 2004 & 378 & 46 & 12.17 & 540 & 429 & 79.44 \\
\hline 2005 & 399 & 28 & 7.02 & 386 & 257 & 66.58 \\
\hline 2006 & 407 & 86 & 21.13 & 478 & 347 & 72.59 \\
\hline 2007 & 280 & 43 & 15.36 & 459 & 319 & 69.50 \\
\hline 2008 & 700 & 90 & 12.86 & 559 & 375 & 67.08 \\
\hline 2009 & 247 & 42 & 17.00 & 414 & 177 & 42.75 \\
\hline 2010 & 411 & 29 & 7.06 & 414 & 238 & 57.47 \\
\hline 2011 & 422 & 25 & 5.92 & 389 & 206 & 52.96 \\
\hline 2012 & 509 & 31 & 6.09 & 227 & 136 & 59.19 \\
\hline 2013 & 631 & 24 & 3.90 & 333 & 140 & 42.04 \\
\hline
\end{tabular}

to have significant and long-lasting impacts on shoreline salt marshes (Lin \& Mendelssohn, 2012) and on wetlands more generally (Mendelssohn et al., 2012). In the Wadden Sea area, therefore, specific measures are in place to control discharges for ships under MARPOL Annexes (IMO, 2017b).

Effectively, any visible oil slick in the North Sea which is identified as having come from a ship, unless it is the result of an accident, can be considered to be intentional or illegal since spills on the sea surface generally become visible only above the $15 \mathrm{ppm}$ level (Bonn Agreement, 2004, p. 101). Oil discharges are permissible, outside SAs or PSSAs at specific distances from land (more than 50 miles for tankers under the 1992 Amendment to MARPOL Annex I).

Oil spill detections by country

Bonn Agreement data can be used to identify trends across the whole North Sea region and by individual country, as illustrated in Table 3. For example, in 1997, there was a large increase in observed spills across the region, up from 650 in 1996-1181 in 1997. There was a corresponding large increase in observed spills in Netherlands waters (up from 247 in 1996 to 771 in 1997) although there was only a small increase in the number of Netherlands flight hours (up from 897 in 1996 to 970 in 1997). The large increase in observed slicks is likely the result of spills from ships travelling through Netherlands waters, either into large ports such as Rotterdam and Amsterdam, or onward towards the entrance to the Baltic Sea; there are very few oil installations in Netherlands waters, ruling these out as a likely source.

Since 1997 the number of spills continued to fall across the whole region so that, by 2013 , the total number of spills was only 15\% of the total for 1997. The number of spills also declined in Netherlands waters, from a high of 771 in 1997 to 15 in 2012, 31 in 2013. This decline is, according to Camphuysen \& Vollaard (2015) reflected in a reduction in the number of stranded oiled seabirds being reported each winter in the Netherlands sector of the North Sea in recent decades. This is further supported by Camphuysen \& Heubeck (2015) who identify that there has been a decline over several decades in chronic oil pollution of the North Sea based on trends from annual beached bird surveys (surveys assessing the number of oiled seabirds washing ashore each winter) and this is also reflected more broadly across Europe.

From 2003 onwards, the figures in Table 3 refer to aerial detections that have been confirmed as oil spills rather than just the number of detections which may or may not be from oil spills. For example, there were 290 spill detections by flights conducted out of the Netherlands in 2003, of which only 191 were confirmed as oil; the smaller number has been used in Table 3. The difference between the detected and confirmed spill numbers for the Netherlands can be explained by the much higher number of night flights conducted by the Netherlands than other CPs, and the very high number of night observations. Many night 
Table 3 Comparison of observed oil slicks by country 1990-2013. Source Bonn Agreement Annual Aerial Surveillance Reports 1998 to 2014

\begin{tabular}{|c|c|c|c|c|c|c|c|c|}
\hline Year & Belgium & Denmark & Germany & Netherlands & Norway & Sweden & UK & All \\
\hline 1990 & 0 & 65 & 130 & 362 & 0 & 26 & 180 & 763 \\
\hline 1991 & 16 & 91 & 51 & 273 & 66 & 15 & 135 & 647 \\
\hline 1992 & 60 & 27 & 135 & 202 & 98 & 6 & 191 & 719 \\
\hline 1993 & 60 & 4 & 99 & 279 & 113 & 6 & 180 & 741 \\
\hline 1994 & 82 & 10 & 122 & 283 & 80 & 6 & 147 & 736 \\
\hline 1995 & 57 & 17 & 98 & 238 & 72 & 16 & 176 & 681 \\
\hline 1996 & 42 & 13 & 121 & 247 & 93 & 21 & 108 & 650 \\
\hline 1997 & 58 & 36 & 125 & 771 & 60 & 14 & 89 & 1181 \\
\hline 1998 & 70 & 57 & 120 & 458 & 72 & 31 & 69 & 922 \\
\hline 1999 & 61 & 74 & 118 & 450 & 65 & 36 & 58 & 884 \\
\hline 2000 & 54 & 33 & 120 & 187 & 46 & 8 & 75 & 548 \\
\hline 2001 & 54 & 114 & 93 & 266 & 64 & 15 & 54 & 676 \\
\hline 2002 & 45 & 74 & 94 & 130 & 55 & 15 & 66 & 533 \\
\hline 2003 & 82 & 47 & 53 & 191 & 23 & 9 & 31 & 458 \\
\hline 2004 & 36 & 43 & 3 & 109 & 65 & 10 & 46 & 339 \\
\hline 2005 & 3 & 57 & 54 & 71 & 14 & 15 & 27 & 263 \\
\hline 2006 & 9 & 69 & 92 & 98 & 17 & 7 & 26 & 347 \\
\hline 2007 & 25 & 75 & 47 & 37 & 25 & 3 & 85 & 319 \\
\hline 2008 & 22 & 134 & 48 & 42 & 14 & 6 & 77 & 375 \\
\hline 2009 & 13 & 34 & 30 & 47 & 19 & 3 & 38 & 200 \\
\hline 2010 & 22 & 125 & 30 & 69 & 13 & 4 & 10 & 283 \\
\hline 2011 & 7 & 40 & 24 & 18 & 50 & 7 & 50 & 216 \\
\hline 2012 & 5 & 55 & 20 & 15 & 28 & 3 & 7 & 141 \\
\hline 2013 & 16 & 37 & 22 & 31 & 38 & 15 & 13 & 176 \\
\hline
\end{tabular}

observations were subsequently ruled out as being mineral oil following visual verification during daylight hours. With all other reductions based on confirmation of detections, the number of confirmed slicks across all countries was 458 compared to 592 prior to confirmation. The level of uncertainty in the surveillance data is considered very low once factors such as night observations being subsequently ruledout as mineral oil are taken into account.

The waters off the coast of Belgium have also seen a reduction in oil spills and a significant decrease in chronic oil pollution pressure over time. Schallier \& Van Roy (2015) examined a detailed statistical analysis of the Belgian oil slick database following 20 years of aerial surveillance in the Belgian Surveillance Area. That analysis identified a statistically significant decrease in the annual number of oil spills, the total polluted surface area, and the estimated volume of oil entering Belgian waters throughout the period 1991-2013. Schallier \& Van Roy (2015) identify two causes for this; the designation of North West European waters as a Special Area under MARPOL, and the implementation of EU Directive 2000/59/EC on Port Reception Facilities for ShipGenerated Waste etc. (Official Journal, 2000). Under that Directive, European ports are required to provide facilities to remove ship generated wastes, including oily wastes, from vessels calling into a port. In Belgian waters, there has been a significant fall in the numbers of the total number of detected and observed operational oil slicks minor oil spills between the subperiods 1991-1998 and 2006-2013 (Schallier \& Van Roy, 2015). The number of very small spills of less than $0.1 \mathrm{~m}^{3}$ in size fell from 191 in the sub-period 1991-1998 to 76 in the sub-period 2006-2013. During the same sub-periods, the total number of minor spills between 0.1 and $1 \mathrm{~m}^{3}$ fell from 128 to 24; medium slicks $\left(1-10 \mathrm{~m}^{3}\right)$ from 53 to 11 ; and major slicks (more than $10 \mathrm{~m}^{3}$ ) from 15 to 0 . 


\section{Trends in oil pollution from oil and gas production in the North Sea}

The North Sea has been the site of Europe's offshore oil and gas production industry since the 1960s, with oil installations generally in the area lying between the north-east UK and south west Norway and gas installations in the southern North Sea, between the UK and the Netherlands (North Sea Task Force, 1993, p. 17). In March 2017, there were more than 1350 offshore installations operational in the OSPAR maritime area, the majority of which are sub-sea installations and fixed steel installations in the waters of Denmark, Germany, Ireland, the Netherlands, Norway, Spain and the UK, rather than oil production installations (OSPAR Commission, 2017). Figure 3 sets out the number of oil installations in Denmark, the Netherlands, Norway and the UK that were in production (i.e., excluding all facilities where no production activities were occurring) between 2001 and 2012. Figure 4 illustrates the location of oil and gas production platforms, oil wells, exploration drillings and oil pipelines in the North Sea region in 2009 (i.e. all facilities, including those where no production activities were occurring) (OSPAR Commission, 2010, p. 65).

The role of the OSPAR Commission

The OSPAR Commission plays an important role in monitoring oil pollution levels from oil and gas installations, whether from operational sources or accidental spills. Information collected by the OSPAR Commission includes quantities of water discharged each year together with the annual average oil content, and the total amount of oil discharged (in tonnes). Discharge sampling from both manned and unmanned installations, together with the use of gas chromatography since 2007 (previously infrared detection) enables the OSPAR Commission to determine the dispersed oil content in produced water in a sample, to ensure that installations meet all the relevant standards (OSPAR Commission, 2011a).

Each OSPAR CP collects various data on discharges, spills and emissions from offshore oil and gas installations, and these data are compiled into OSPAR annual reports (OSPAR Commission, 2016, p. 7), which reports are providing details on installations that have failed to meet the relevant performance

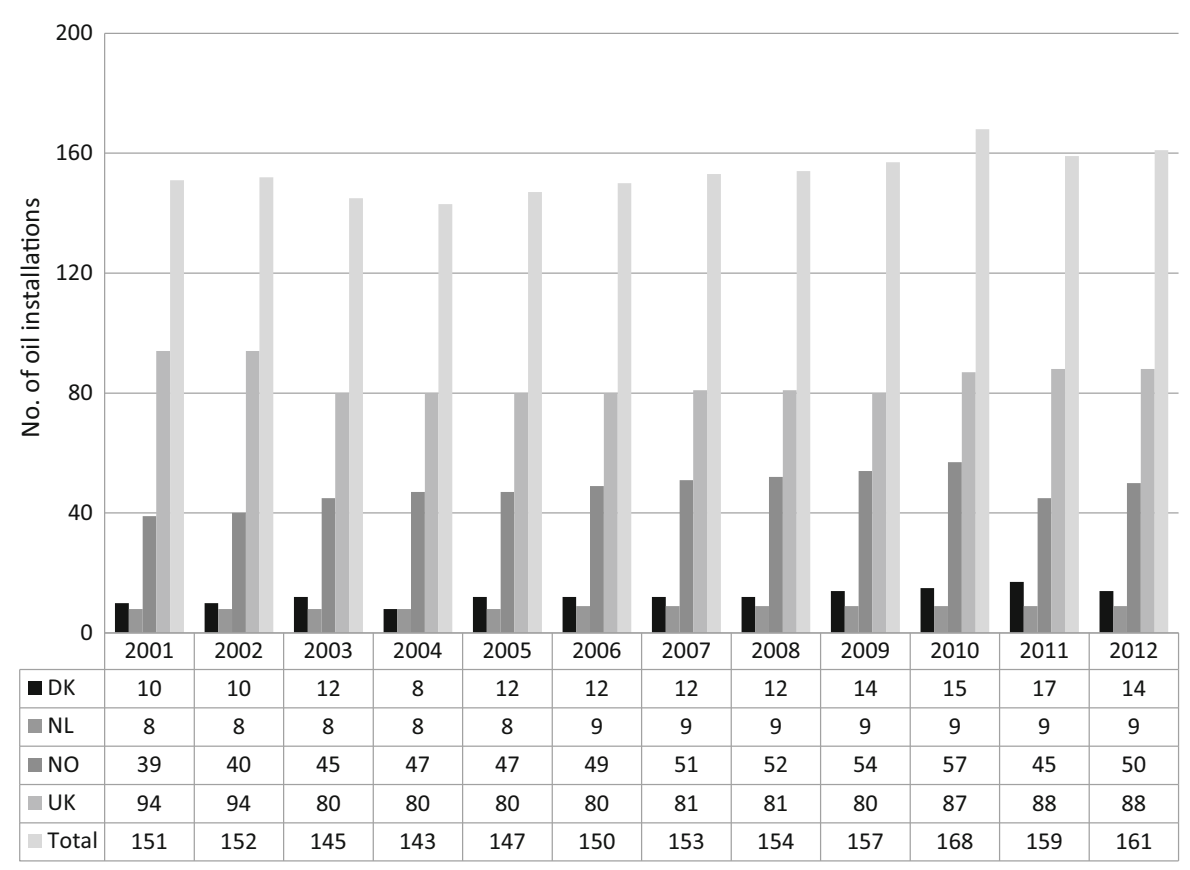

Fig. 3 Number of oil production installations in the North Sea with emissions and discharges covered by OSPAR Measures. Source Carpenter (2016: p. 225, Fig. 8a) 
Fig. 4 Offshore oil and gas fields under exploitation, new discoveries not yet in production and pipelines in 2009. Source OSPAR

Commission (2010, p. 64, Fig. 7.2)

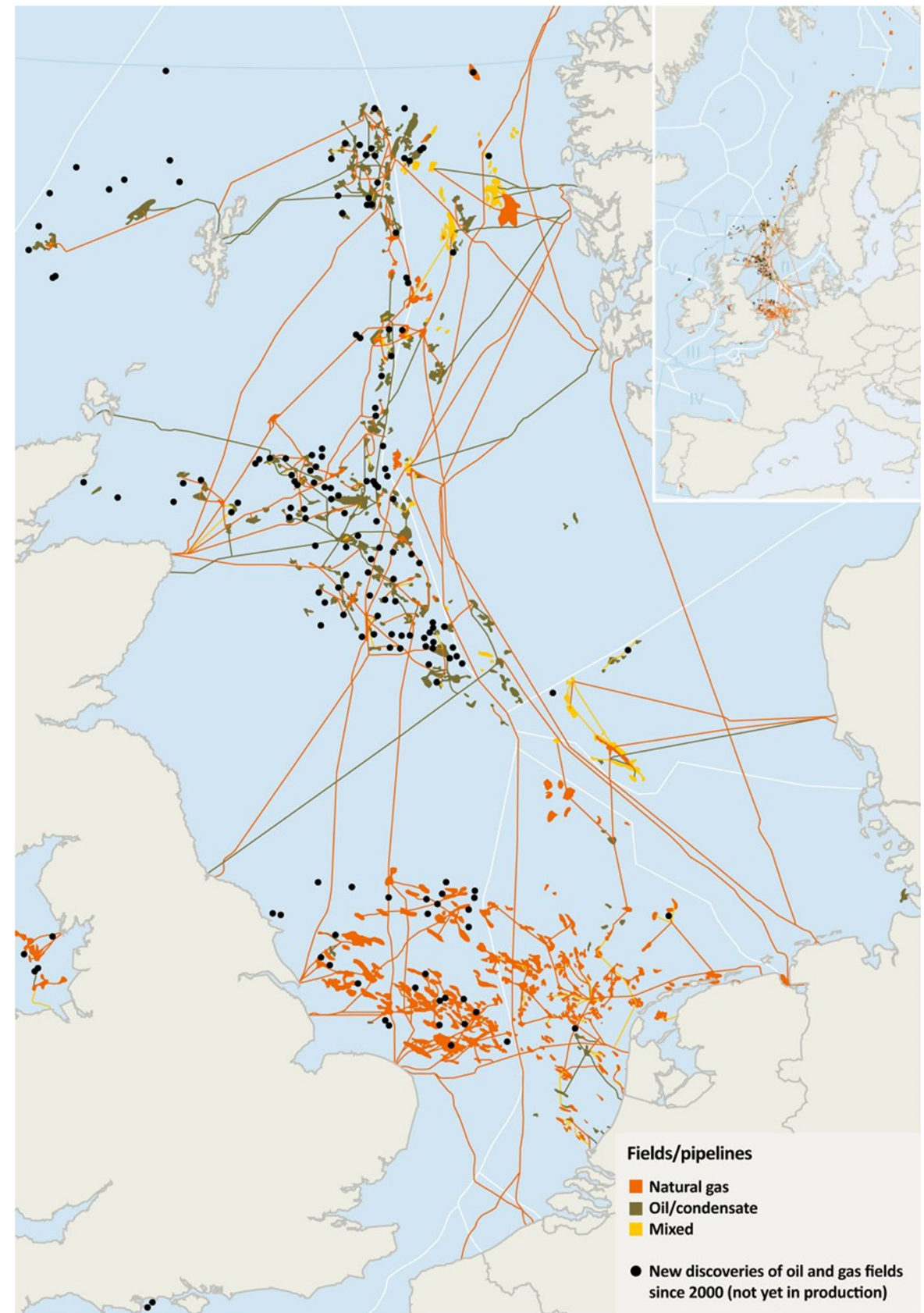

standards (OSPAR Commission, 2016, pp. 13-17). Those standards include, for example, an average concentration of hydrocarbons discharged in effluents from oil installations (produced water (PW), displacement water (DW), ballast water, drainage water, etc.) set at $40 \mathrm{mg} / \mathrm{l}$ for discharges from platforms built after 1 January 1998 (Paris Commission, 1986), and a specific recommendation for the management of $\mathrm{PW}$ from offshore installations to be reduced to $30 \mathrm{mg} / \mathrm{l}$ oil in water concentration, that came into force in 2007 (OSPAR Commission, 2001b). The $40 \mathrm{mg} / \mathrm{l}$ concentration continued to apply to DW, drainage, and ballast water. However, the 40 and $30 \mathrm{mg} / \mathrm{l}$ standards both refer to a monthly average concentration, rather than an absolute emissions standard such as the $15 \mathrm{ppm}$ standard for ships under MARPOL Annex I. The Bonn 
Agreement (2012b, p. 11) indicated that discharges from installations could reach $800 \mathrm{ppm}$, resulting in a discrepancy between observed spills and what was reported to the OSPAR Offshore Industry Committee (OIC).

Sources of oil pollution from oil and gas installations

Oil pollution from oil and gas platforms can come from a number of different sources including accidental spills and operational discharges, as illustrated in Fig. 5. Accidental spills are quite rare and are generally small in size. In 2003, while there were 640 accidental spills in total, the vast majority (621) were less than 1 tonne by volume and only 19 were over 1 tonne by volume. By 2012, there were 421 spills (411 less than 1 tonne by volume, 10 over 1 tonne by volume). During all these years, the majority of such spills occurred in the UK and Norwegian watersthese countries having the location of the majority of oil installations in the North Sea region.

As identified in Fig. 1, the Bonn Agreement has undertaken aerial surveillance activities across the region to identify oil spills and their sources. Between 1997 and 2013, there was a reduction in the number of confirmed spills identified as coming from oil installations (from 81 to 37), supporting evidence from OSPAR that accidental oil spills from installations fell by around one-third between 2004 and 2012 (OSPAR Commission, 2012). While the source of $80 \%$ of oil spills was not verified in Fig. 1, it is considered likely that those sources would have been ships travelling through the region, rather than fixed installations such as oil platforms.

In terms of operational discharges, since the early 2000s, the main source of oil discharge is PW. PW is generally water trapped in underground formations that comes to the surface as a by-product of oil and gas extraction and contains hazardous substances such as heavy metals, aromatic hydrocarbons and other substances including chemicals used in the oil production process. PW can also be water that is injected into the oil reservoir to stimulate pressure and increase yields from ageing oil fields. Other substances released from platforms that can contain oil are DW, the seawater used for ballasting storage tanks which is discharged into sea when oil is loaded into those tanks, together with drilling fluids and cuttings. Drilling fluids such as organic-phase drilling fluids (OPFs) are an emulsion of water and other additives in which the continuous phase is a water-immiscible organic fluid of animal,

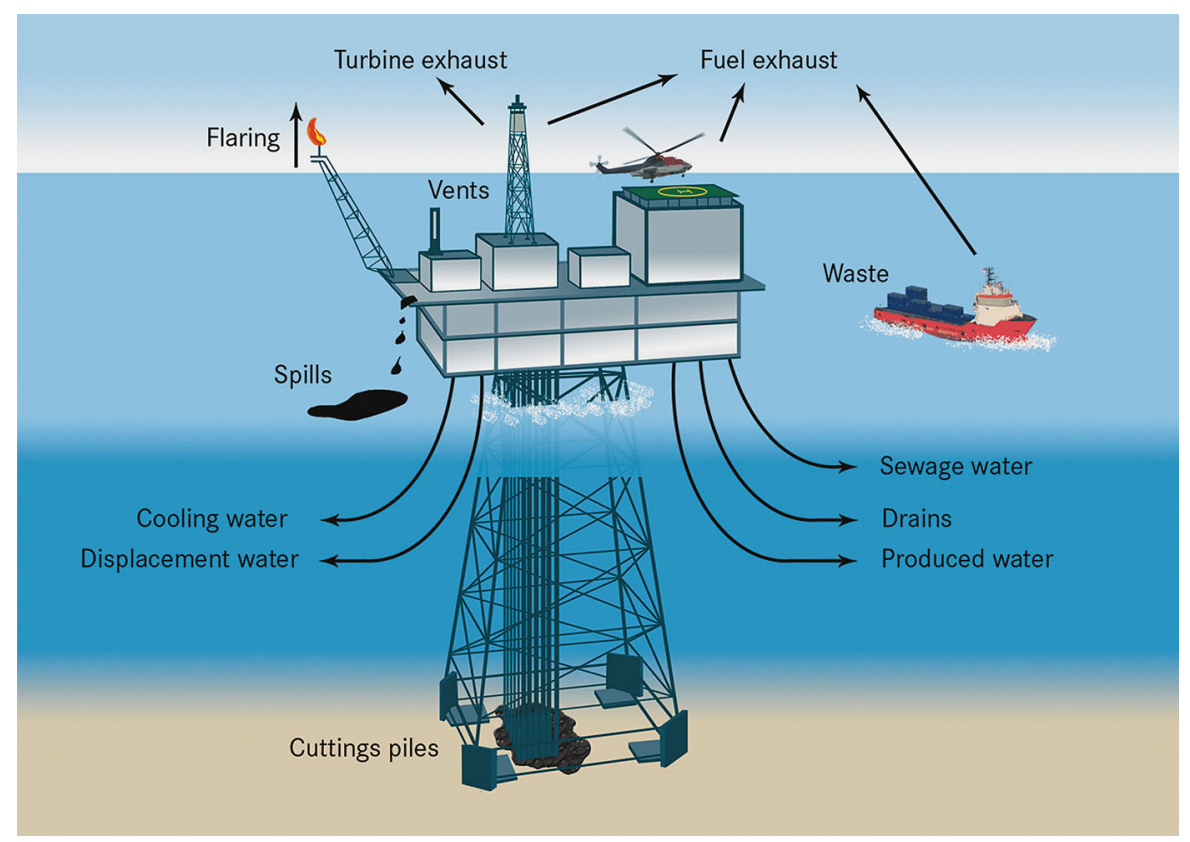

Fig. 5 Substances released from a range of sources during routine offshore oil and gas production. Source OSPAR Commission (2010, p. 65, Fig. 7.3) 
vegetable or mineral origin. Cuttings are solid material removed from drilled rock together with any solids and liquids derived from any adherent drilling fluids. Cuttings can have a significant impact on taxa, abundance, biomass and diversity around oil installations (Schaanning et al., 2008; Trannum et al., 2010), with those impacts lasting for many years (Jones et al., 2012).

In the early 1980 s, it was recognised that there were elevated levels of hydrocarbons in the sediments around drilling platforms extending out to a distance of $3000 \mathrm{~m}$ in some cases, and that those hydrocarbons were the result of the discharge of oiled drill cuttings containing diesel oil (Leaver et al., 1987). In 1984, around $5 \%$ of the North Sea wells being drilled used diesel-based muds, while $75 \%$ were drilled using lower toxicity oil-based muds (Leaver et al., 1987). Despite this change, Kingston et al. (1987) noted that there were dramatic drops in fauna out to between 500 and $1000 \mathrm{~m}$, irrespective of whether diesel or lower toxicity oil-based drilling fluids were used. Since 1996, there have been no discharges of oil-mudcontaminated cuttings (OSPAR Commission, 2001a), and since 2004, virtually no OPFs and cuttings have been discharged in the North Sea region (OSPAR Commission, 2012). However, research into impacts on cold-water coral colonies has shown that cuttings can have a major impact on colony size and mortality (Gass \& Roberts 2006; Allers et al., 2013; Larsson et al., 2013), while drilling activities more generally can have an impact on the density of motile organisms close to drilling platforms (Jones et al., 2012).

While some substances discharged from oil installations were found in sediments around Danish, Netherlands, Norwegian and the UK rigs with high, but very localised impacts, throughout the 1980s and 1990s, these concentrations have reduced significantly in recent years, and environmental conditions around rigs have improved (OSPAR Commission, 2010, p. 68). Much of this improvement can be considered the result of stringent emission standards, discussed previously. In the example of the UK offshore industry, the average concentration of oil discharged with PW across the industry was $14.2 \mathrm{mg} / \mathrm{l}$ in 2015 , less than half the OSPAR $30 \mathrm{mg} / \mathrm{l}$ limit, with around 2300 tonnes of oil discharged in PW $(0.001 \%$ of total PW discharged), and the volume of PW discharged into sea had fallen from 263 million $\mathrm{m}^{3}$ to 165 million $\mathrm{m}^{3}$ since 2000 (Oil and Gas UK, 2016).
In 2001, the OSPAR Commission established an Offshore Industry Committee (OIC) to work towards protecting the marine environment of the North Sea and its resources in respect of offshore oil and gas (OSPAR Commission, 2001c). Subsequently in 2011, the OIC was given responsibility for facilitating implementation of the OSPAR North East Atlantic Environment Strategy which required the OIC to: (a) develop and apply a risk-based approach for management of PW from offshore activities; (b) keep under review the need for actions to prevent potential adverse effects from offshore activities; and (c) consider implications of decommissioning redundant oil and gas installations (OSPAR Commission, 2011b). This latter is particularly important as decommissioning of installations could cause significant disturbance of drilled cuttings and release contaminants back into the marine environment (Henry et al., 2017).

Operational discharges from oil and gas installations

As a result of the various standards set for discharges via $\mathrm{PW}$ and DW there has been a decline in the quantity of oil being discharged into the North Sea. As illustrated in Fig. 6, Carpenter (2016) identifies that the volume of PW discharged fell from almost 400 million $\mathrm{m}^{3}$ in 2001 to 318.48 million $\mathrm{m}^{3}$ in 2012, a fall of around $20 \%$. The volume of DW also fell between 2001 and 2012 from 67.75 million $\mathrm{m}^{3}$ in 2001 to 34.4 million $\mathrm{m}^{3}$ in 2012 , a fall of almost $50 \%$. The amount of PW injected into ageing wells rose by over $300 \%$ between 2001 and 2012 (from 30.27 million $\mathrm{m}^{3}$ to 92.13 million $\mathrm{m}^{3}$ ). The dotted line in Fig. 6 represents the combined total for PW discharged and injected,

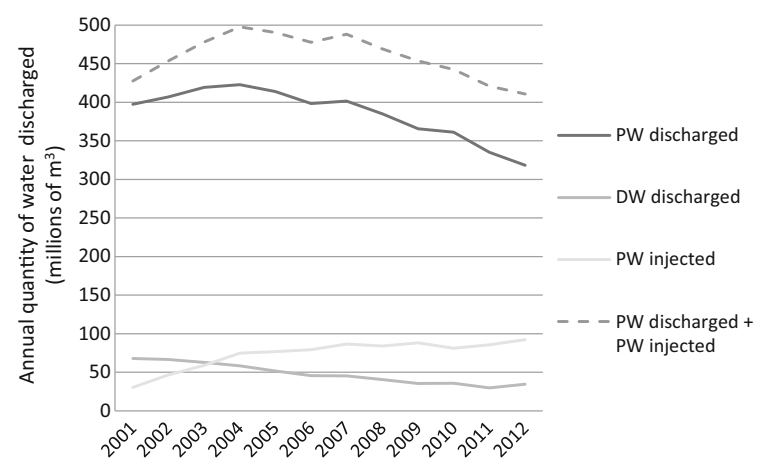

Fig. 6 Annual Quantities of PW and DW discharged into the North Sea 2001-2012. Source Carpenter (2016, p. 228, Fig. 10) 
illustrating the change from discharging PW into the sea to reinjecting it into the reservoir. There was little change in the combined volume between 2001 and 2012 (427.6 million $\mathrm{m}^{3}$ and 410.61 million $\mathrm{m}^{3}$, respectively).

Figure 7 illustrates the actual quantity of oil (in tonnes) discharged via PW and DW into the sea and shows that a significant change occurred between 2001 and 2012. Almost 14 million tonnes of oil were discharged into sea in PW in 2001, falling to just under 4 million tonnes in 2012, i.e. less than $30 \%$ of the 2001 volumes. Although the quantities discharged in DW were much smaller, there was also a fall between 2001 and 2012 from 262.2 tonnes to 61.4 tonnes, i.e. less than $20 \%$ of 2001 levels. Overall, operational discharges from oil installations have significantly improved in recent years. This is supported by the Norwegian Oil and Gas Association (2010) which indicates that discharges of environmentally harmful chemicals had declined by $99.5 \%$ since 1987 , noting, however, that further reduction in discharges of oil and naturally occurring environmental toxins in $\mathrm{PW}$ remains a challenge, and illustrate the need for continuing monitoring and improvement in management strategies dealing with exposure to waste production products (PW) around platforms (Purser \& Thomsen, 2012).

Problems remain in regards to the offshore industry. The Norwegian Environment Agency (2016) identifies drilling wastes from offshore activities as being a continuing issue, with about 465,000 tons of hazardous waste taken ashore in 2015 (38,000 tons more than in 2014), of which the largest fraction is drilling wastes $(82.10 \%$; 402,895 tons) while oily waste makes up only $2.14 \%$ (2,613 tons). Drilling wastes had risen

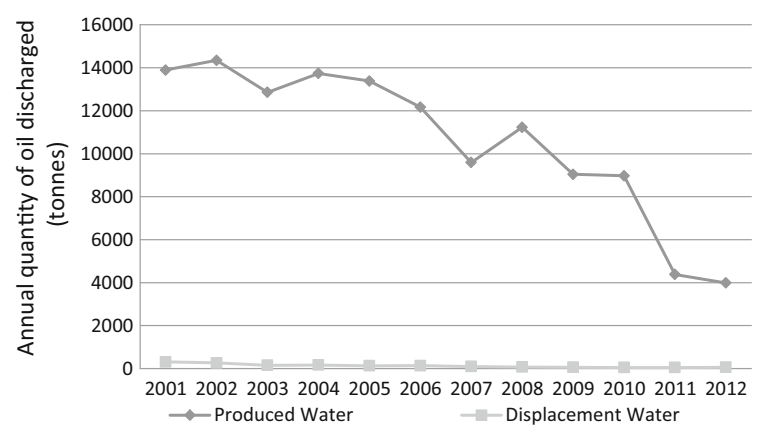

Fig. 7 Annual quantity of oil (in tonnes) discharged via PW and DW, 2001-2012. Source Carpenter (2016, p. 228, Fig. 11) from 115,821 tons in 2005 , and so had more trebled in the intervening 10 years. The issue facing the offshore sector in Norwegian waters is the difficulty of injecting drill cuttings underground across several fields on its continental shelf, a common practice elsewhere in the North Sea. Despite this issue, in relation to oily waste, discharges amounted to 2,613 tonnes in 2014 (2.14\% of hazardous waste taken ashore) and so, in that context, oily waste is only a minor contributor to the total waste coming from Norwegian installations.

\section{Potential area for further study}

Significant reductions in oil pollution from both shipping and from oil and gas installations have been identified over more than two decades. However, there remain some areas where further action is needed to reduce inputs still further. As an example, oil pollution in Danish waters comes from both shipping and from offshore platforms, and more recently from offshore wind systems. As Porathe \& Ottmann (2015) note, wind farms are planned for the waters of the UK, Denmark, Norway and Germany. These not only provide a potential hazard to ships through reduced room to navigate and manoeuver, but also introduce the possibility of increasing numbers of small spills, as has already been seen in Danish waters (Christensen \& Carpenter, 2015).

Between 2009 and 2013, the number of reported observations and the number of observations confirmed as oil increased in Danish waters. Christensen \& Carpenter (2015) identified that there were 175 observed spills in 2009 of which 30 were confirmed as oil, a $17 \%$ confirmation rate. However, in 2013, there were 232 observed and 91 confirmed spills, a confirmation rate of just under $40 \%$. The increase in reported spills between 2009 and 2013 appears to be the result of higher numbers of small spills coming from oil platforms and offshore wind systems, and improved reporting of such spills by the operators of those offshore installations to land-based authorities. The number of observed discharges from ships declined by 68\% during the same period (Christensen \& Carpenter, 2015).

From Table 3, the aerial surveillance data for Danish waters also illustrate wide variations between the years in the number of observed spills, while Fig. 8 


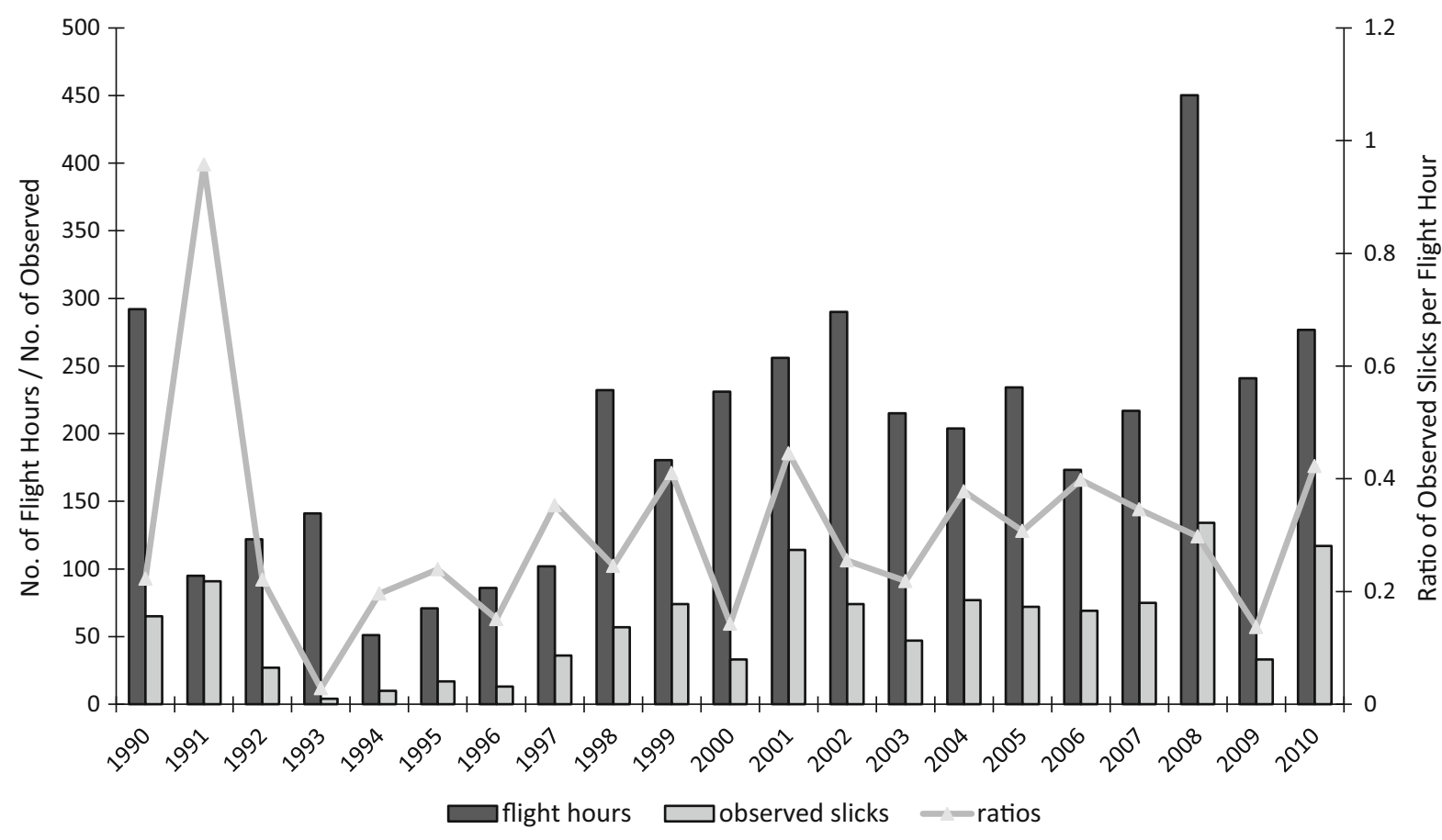

Fig. 8 Flight hours, observed slicks and their ratios in the Danish North Sea area 1990-2010. Source Bonn Agreement Annual Aerial Surveillance Reports 1990-2010

illustrates that there continued to be fairly high levels of observed slicks per flight hour in the Danish North Sea area from aerial surveillance data. For example, in 1990 , there were $292 \mathrm{~h}$ of aerial surveillance flights, but only $51 \mathrm{~h}$ in 1994 . There were 10 observed slicks in 1994, giving a ratio of 0.22 slicks per flight hour. In 1991, there were 91 slicks observed during 95 flight hours, a ratio of almost 1 slick per flight hour. While that was the worst year in terms of the ratio of slicks per flight hour, other years saw quite high ratios: 0.41 in 1999, 0.45 in 2001 and 0.42 in 2010 (i.e. almost 1 spill every $2 \mathrm{~h}$, for example). This is not reflected in other North Sea states. Table 4 illustrates the ratio of spills per flight hour by country between 1991 and 2010 , and shows that by 2010 , the ratio has fallen to 0.06 spills per flight hour or less (i.e. approximately 1 spill every 17 flight hours) for all countries other than Denmark.

\section{Conclusions}

This paper illustrates that international cooperation can result in a reduction in marine pollution by oil.
Legal measures at international, regional, the EU and national levels mean that operational discharges from ships are strictly controlled, particularly since the designation of the North West European waters, including the North Sea, as a Special Area under MARPOL. At the same time, aerial surveillance conducted under the aegis of the Bonn Agreement, together with the introduction of satellite surveillance technology and the surveillance activities conducted under EMSA operational tasks, offers a tool for environmental monitoring and increases the potential to identify the source of a pollution incident, raising the possibility of polluters being prosecuted for their actions.

As a result of the various actions and measures taken to reduce oil pollution entering the marine environment of the North Sea, the annual total number of oil spills in the region have declined over more than two decades from all sources, while the ratio of observed slicks by flight hours fell from 0.22 in 1999 to 0.04 in 2010 for the whole region. Increasing accuracy of aerial and satellite surveillance, together with activities to confirm whether a slick is mineral oil or some other substance means that data have become 
Table 4 Comparison of flight hours versus observed spills (ratio of spills/flight hour), 1991-2010. Source Bonn Agreement Annual Aerial Surveillance Reports 1991 to 2011

\begin{tabular}{llllllll}
\hline Year & Belgium & Denmark & Germany & Netherlands & Norway & Sweden & UK \\
\hline 1991 & 0.21 & 0.96 & 0.13 & 0.39 & 0.09 & 0.19 & 0.25 \\
1992 & 0.32 & 0.22 & 0.21 & 0.41 & 0.14 & 0.05 & 0.30 \\
1993 & 0.28 & 0.03 & 0.20 & 0.39 & 0.12 & 0.05 & 0.27 \\
1994 & 0.40 & 0.20 & 0.19 & 0.30 & 0.09 & 0.03 & 0.22 \\
1995 & 0.28 & 0.24 & 0.14 & 0.29 & 0.17 & 0.10 & 0.20 \\
1996 & 0.19 & 0.15 & 0.15 & 0.28 & 0.24 & 0.13 & 0.11 \\
1997 & 0.26 & 0.35 & 0.16 & 0.79 & 0.12 & 0.07 & 0.10 \\
1998 & 0.28 & 0.25 & 0.14 & 0.62 & 0.13 & 0.13 & 0.08 \\
1999 & 0.25 & 0.41 & 0.12 & 0.69 & 0.12 & 0.12 & 0.08 \\
2000 & 0.39 & 0.14 & 0.12 & 0.24 & 0.12 & 0.09 & 0.12 \\
2001 & 0.34 & 0.45 & 0.10 & 0.47 & 0.16 & 0.14 & 0.09 \\
2002 & 0.32 & 0.26 & 0.10 & 0.26 & 0.09 & 0.10 & 0.13 \\
2003 & 0.40 & 0.22 & 0.08 & 0.39 & 0.06 & 0.05 & 0.04 \\
2004 & 0.20 & 0.38 & 0.12 & 0.26 & 0.14 & 0.04 & 0.07 \\
2005 & 0.04 & 0.31 & 0.05 & 0.10 & 0.04 & 0.05 & 0.04 \\
2006 & 0.06 & 0.40 & 0.09 & 0.09 & 0.04 & 0.04 & 0.04 \\
2007 & 0.11 & 0.35 & 0.05 & 0.06 & 0.06 & 0.04 & 0.18 \\
2008 & 0.13 & 0.30 & 0.06 & 0.03 & 0.06 & 0.03 & 0.11 \\
2009 & 0.09 & 0.14 & 0.03 & 0.04 & 0.06 & 0.01 & 0.06 \\
2010 & 0.06 & 0.42 & 0.04 & 0.05 & 0.06 & 0.02 & 0.01 \\
\hline & & & & & & & \\
\hline
\end{tabular}

ever more accurate. After 1998, evidence also indicates that the majority of oil spills are generally less than $1 \mathrm{~m}^{3}$ by volume, and that chronic oil pollution has declined across the region, making it much cleaner than in the past.

Moving forward, tools to rapidly identify spills at sea and confirm whether a spill is oil or not, identify ships in the region of a spill, and also match a spill sample with oil from a potential ship source, should further drive down intentional, illegal pollution while the risk of being caught, prosecuted and fined has increased. At the same time, accidental spills from ships are now very infrequent due to better ship designs and anti-collision measures in the region's busy shipping lines, for example.

However, there still remain some issues where further action may be necessary. In particular, some agreed discharges remain permissible and these have made up the main input in recent years. In addition, Dixon (2015) identified that in 2014 alone, there were 601 accidental releases of oil and chemicals from offshore oil and gas installations operations in the open sea in the UK waters-a $14.5 \%$ increase on the 2013 total. Of those accidental releases, there were 380 mineral oil releases from offshore oil and gas installations in all the UK waters, the highest recorded number since 2000 and 101 more than the mean annual total of 279 releases reported between 2000 and 2013. However, the majority of these releases $(70 \%)$ were estimated to be less than 51 , based on figures reported by offshore oil and gas installations (Dixon, 2015).

There also remains a level of uncertainty in the discharge data for offshore installations. The Bonn Agreement has made use of its Oil Appearance Code (Bonn Agreement, 2011) together with laboratory and other testing to estimate volumes of oil spills from offshore installations, while OSPAR uses CP data based on average emissions, and this can lead to discrepancies in reported volumes of oil in a spill (Bonn Agreement, 2014b, p. 24). That discrepancy was officially reported by the Bonn Agreement to the OSPAR OIC (Bonn Agreement, 2012b, p. 11).

A further issue is the ageing nature of oil production platforms in the region, and this may lead to more accidents in the future, either due to an increasing need for maintenance of ageing equipment, or due to discharges occurring during decommissioning of platforms. The OSPAR Commission (2010, p. 63) identifies activities such as plugging wells and removing infrastructure as posing a threat, while 
Henry et al. (2017) identify both the persistence of drill cuttings from development and operation of oil platforms in the UK sector of the North Sea, and the release of contaminants contained in these cuttings during the decommissioning of a platform, with impacts likely to be longer lasting in the deeper Northern and central North Sea regions, the location of the majority of oil platforms.

While it can be concluded that the situation regarding inputs of oil to the North Sea has improved dramatically over the last several decades, particularly in areas such as ship safety and strict operational standards, and through the designation of the North Sea as having Special Status under MARPOL and the Wadden Sea having Particularly Sensitive Sea Area Status, more action still needs to be taken in respect of oil installations, for example. Monitoring activities such as those conducted by the Bonn Agreement and the OSPAR Commission remain vital in maintaining any improvements. However, it can also be concluded that where regional cooperation takes place, it is possible to have a positive impact on an environmental issue, and in doing so, reduce the risk of harm to marine biodiversity. Collaboration among the North Sea states therefore provides a very positive example of how concerted action by state actors, along with legislative measures, has been effective in reducing marine pollution in the region over many decades.

Open Access This article is distributed under the terms of the Creative Commons Attribution 4.0 International License (http:// creativecommons.org/licenses/by/4.0/), which permits unrestricted use, distribution, and reproduction in any medium, provided you give appropriate credit to the original author(s) and the source, provide a link to the Creative Commons license, and indicate if changes were made.

\section{References}

Allers, E., R. M. M. Abed, L. M. Wehrmann, T. Wang, A. I. Larsson, A. Purser \& D. de Beer, 2013. Resistance of Lophelia pertusa to coverage by sediment and petroleum drill cuttings. Marine Pollution Bulletin 74: 132-140.

Bedborough, D. R., R. A. A. Blackman, R. J. Law, R. E. Jones \& J. G. Parker, 1987. A survey of inputs to the North Sea resulting from oil and gas developments. Philosophical Transactions of the Royal Society of London, Series B, Biological Sciences 316: 495-509.

Bonn Agreement, 2001. Text of the Bonn Agreement, Volume 3, Chapter 29. Agreement for cooperation in dealing with pollution of the North Sea by oil and other harmful substances, 1983 as amended by a decision of 21 September 2001 etc. London: Bonn Agreement.

Bonn Agreement, 2004. Bonn Agreement Aerial Surveillance Handbook. Bonn Agreement, London.

Bonn Agreement, 2011. Bonn Agreement Oil Appearance Code-Photo Atlas. Version 23/06/2011. Bonn Agreement, London.

Bonn Agreement, 2012a. Bonn Agreement Aerial Operations Handbook, 2009, Revision 2 of April 2012. Bonn Agreement, London.

Bonn Agreement, 2012b. Summary Record OTSOPA 2012. OTSOPA 12/13/1-E, Agenda item 13, Lisbon: 22-24 May 2012. Bonn Agreement, London.

Bonn Agreement, 2014a. Bonn Agreement BE-AWARE II Project. Bonn Agreement, London.

Bonn Agreement, 2014b. Bonn Agreement Aerial Surveillance Programme: Annual Report on Aerial Surveillance for 2014. Bonn Agreement, London.

Bonn Agreement, 2016. Bonn Agreement Aerial Operations Handbook 2016. Bonn Agreement, London.

Camphuysen, C. J. \& B. Vollaard, 2015. Oil Pollution in the Dutch Sector of the North Sea. In Carpenter, A. (ed.), Oil Pollution in the North Sea. Handbook of Environmental Chemistry, Vol. 41. Springer International Publishing, Switzerland: 117-140.

Camphuysen, C. J. \& M. Heubeck, 2015. Beached Bird Surveys in the North Sea as an Instrument to Measure Levels of Chronic Oil Pollution. In Carpenter, A. (ed.), Oil Pollution in the North Sea. Handbook of Environmental Chemistry, Vol. 41. Springer International Publishing, Switzerland: 193-208.

Carpenter, A., 2016. Monitoring Oil Pollution from Oil and Gas Installations in the North Sea. In Carpenter, A. (ed.), Oil Pollution in the North Sea. Handbook of Environmental Chemistry, Vol. 41. Springer International Publishing, Switzerland: 209-236.

Christensen, L. \& A. Carpenter, 2015. Oil Pollution in the Waters of the Danish North Sea. In Carpenter, A. (ed.), Oil Pollution in the North Sea. Handbook of Environmental Chemistry, Vol. 41. Springer International Publishing, Switzerland: 69-92.

Clark, R. B., 2001. Marine Pollution, 5th ed. Oxford University Press, Oxford.

Cohen, J. H., L. R. McCormick \& S. M. Burkhardt, 2014. Effects of dispersant and oil on survival and swimming activity in a marine copepod. Bulletin of Environmental Contamination and Toxicology 92: 381-387.

Dicks, B. \& J. R. Hartley, 1982. The effects of repeated small oil spillages and chronic discharges. Philosophical Transactions of the Royal Society of London, Series B, Biological Sciences 297: 285-307.

Dixon, T., 2015. In Dixon, T. (ed.), Annual Survey of Reported Discharges and Releases attribute to vessels and offshore oil and gas installations operating in the United Kingdom's Exclusive Economic Zone (UK EEZ) 2014. Advisory Committee on Protection of the Sea, Cambridge.

Dunnet, G. M., Y. Samiullah, D. P. Stone \& M. L. Tasker, 1987. Seabirds and North Sea Oil. Philosophical Transactions of the Royal Society of London, Series B, Biological Sciences 316: 513-524. 
European Environment Agency, 2007. Europe's Environment-the Fourth Assessment. European Environment Agency, Copenhagen.

European Maritime Safety Agency, 2015. Earth Observation Services-CleanSeaNet. EMSA, Lisbon.

European Maritime Safety Agency, 2011. SafeSeaNet/Vessel Monitoring System Synergies Pilot Project. EMSA, Lisbon.

Gass, S. E. \& J. M. Roberts, 2006. The occurrence of the coldwater coral Lophelia pertusa (Scleractinia) on oil and gas platforms in the North Sea: colony growth, recruitment and environmental controls on distribution. Marine Pollution Bulletin 52: 549-559.

Henry, L.-A., D. Harries, P. Kingston \& J. M. Roberts, 2017. Historic Scale and persistence of drill cuttings impacts on North Sea benthos. Marine Environmental Research 129: 219-228.

International Maritime Organization, 2015a. International Convention on Civil Liability for Oil Pollution Damage (CLC). IMO, London.

International Maritime Organization, 2015b. International Convention for the Prevention of Pollution from Ships, 1973, as modified by the Protocol of 1987 (MARPOL 73/78). IMO, London.

International Maritime Organization, 2017a. Special Areas under MARPOL. IMO, London.

International Maritime Organization, 2017b. Particularly Sensitive Sea Areas. IMO, London.

Jones, D. O. B., A. R. Gates \& B. Lausen, 2012. Recovery of deep-water megafaunal assemblages from hydrocarbon drilling disturbance in the Faroe-Shetland channel. Marine Ecology Progress Series 461: 71-82.

Kingston, P. F., 1987. Field effects of platform discharges on benthic macrofauna. Philosophical Transactions of the Royal Society of London, Series B, Biological Sciences 316: 545-565.

Kingston, P. F., 2002. Long-term environmental impact of oil spills. Spill Science and Technology Bulletin 7: 53-61.

Kostka, J. E., O. Prakash, W. A. Overholt, S. J. Green, G. Greyer, A. Canion, J. Delgardio, N. Norton, T. C. Hazen \& M. Huettel, 2011. Hydrocarbon-degrading bacteria and the bacterial community response in gulf of Mexico beach sands impacted by the deepwater horizon oil spill. Applied and Environmental Microbiology 77: 7962-7974.

Larsson, A. I., D. van Oevelen, A. Purser \& L. Thomsen, 2013. Tolerance to long-term exposure of suspended benthic sediments and drill cuttings in the cold-water coral Lophelia pertusa. Marine Pollution Bulletin 30: 176-188.

Leaver, M. J., D. J. Murison, J. M. Davies, D. Rafaelli, W. A. Hamilton, J. M. Davies \& R. A. A. Blackman, 1987. Experimental studies of the effects of drilling discharges. Philosophical Transactions of the Royal Society of London, Series B, Biological Sciences 316: 625-640.

Lin, Q. \& I. A. Mendelssohn, 2012. Impacts and recovery of the deepwater horizon oil spill on vegetation structure and function of coastal salt marshes in the Northern Gulf of Mexico. Environmental Science and Technology 46(7): 3737-3743.

Mendelssohn, I. A., G. L. Andersen, D. M. Baltz, R. H. Caffey, K. R. Carman, J. W. Fleeger, S. D. Joye, Q. Lin, E. Maltby, E. B. Overton \& L. P. Rozas, 2012. Oil Impacts on Coastal
Wetlands: implications for the Mississippi River Delta Ecosystem after the Deepwater Horizon Oil Spill. BioScience 62: 562-574.

Molenaar, E. J., 1998. Coastal State Jurisdiction over VesselSource Pollution. Kluwer Law International, London.

North Sea Task Force, 1993. North Sea Quality Status Report 1993. Oslo and Paris Commissions, London.

Norwegian Environment Agency, 2016. Waste from oil and gas activities offshore. Norwegian Environment Agency, Trondheim.

Norwegian Oil and Gas Association, 2010. Zero Discharges. Norwegian Oil and Gas Association, Stavanger.

Official Journal, 2000. Directive 2000/59/EC of the European Parliament and Council of 27 November 2000 on port reception facilities for ship-generated waste and cargo residues. Official Journal L 332 of 28 December 2000, 81-89. Brussels: Official Journal of the European Communities.

Oil and Gas UK, 2016. Oil and Gas UK Environment Report 2016. Oil and Gas UK, London.

OSPAR Commission, 2001a. Discharges, Waste Handling and Air Emissions from Offshore Installations for 1998-1999. OSPAR Commission, London.

OSPAR Commission, 2001b. OSPAR Recommendation 2001/1 for the Management of Produced Water from Offshore Installations. Adopted 2001, Valencia. OSPAR Commission, London.

OSPAR Commission, 2001c. Meeting of the Offshore Industry Committee, Oslo, 13-16 February 2001-Summary Record. OSPAR Commission, London.

OSPAR Commission, 2010. The Quality Status Report 2010 Chapter 7-Offshore Oil and Gas Industry. OSPAR Commission, London.

OSPAR Commission, 2011a. OSPAR Reference Method of Analysis for the Determination of Dispersed Oil Content in Produced Water Agreement 2005-2015 (Amended in 2011). OSPAR Commission, London.

OSPAR Commission, 2011b. Terms of Reference for OSPAR Committees Agreement 2011-2014 2015 Update. Ospar Commission, London.

OSPAR Commission, 2012. Discharges, Spills and Emissions from Offshore Oil and Gas Installations in 2009, Including Assessment of Data Reported in 2008 and 2009. OSPAR Commission, London.

OSPAR Commission, 2016. OSPAR report on discharges, spills and emissions from offshore oil and gas installations in 2014. OSPAR Commission, London.

OSPAR Commission, 2017. Offshore Installations-Webpage. OSPAR Commission, London.

Commission, Paris, 1986. PARCOM Recommendation $86 / 1$ of a $40 \mathrm{mg} / \mathrm{l}$ Emission Standard for Platforms PARCOM 8/12/ 1. Paris Commission, Paris.

Porathe, T. \& Ottmann, J.H., 2015. ACCSEAS Baseline and Priorities Report. Interreg IVB North Sea Region Programme Project Report.

Purser, A. \& L. Thomsen, 2012. Monitoring strategies for drill cutting discharge in the vicinity of cold-water coral ecosystems. Marine Pollution Bulletin 64: 2309-2316.

Schallier, R. \& W. Van Roy, 2015. Oil Pollution in and around the waters of Belgium. In Carpenter, A. (ed.), Oil Pollution in the North Sea. Handbook of Environmental Chemistry, 
Vol. 41. Springer international Publishing, Switzerland: 93-116.

Schaanning, M. T., H. C. Trannum, S. Øxnevad, J. Carroll \& T. Bakke, 2008. Effects of drill cuttings on biochemical fluxes and macrobenthos of marine sediments. Journal of Experimental Marine Biology and Ecology 361: 49-57.

Tansel, B., 2014. Propagation of impacts after oil spills at sea: categorization and quantification of local vs regional and immediate vs delayed impacts. International Journal of Disaster Risk Reduction 7: 1-8.

Trannum, H. C., H. C. Nilsson, M. T. Schaanning \& S. Øxnevad, 2010. Effects of sedimentation from water-based drill cuttings and natural sediment on benthic macrofaunal community structures and ecosystem processes. Journal of Experimental Marine Biology and Ecology 383: 111-121. White, H. K., P.-Y. Hsing, W. Cho, T. M. Shank, E. E. Cordes, A. M. Quattrini, R. K. Nelson, R. Camilli, A. W. J. Demopoulos, C. R. German, J. M. Brookes, H. H. Roberts, W. Shedd, C. M. Reddy \& C. R. Fisher, 2012. Impact of the Deepwater Horizon oil spill on a deep-water coral community in the Gulf of Mexico. PNAS 109: 20303-20308. 